\title{
Nota
}

\section{EFFECT OF WATER AVAILABILITY ON SOIL MICROBIAL BIOMASS IN SECONDARY FOREST IN EASTERN AMAZONIA}

\author{
Lívia Gabrig Turbay Rangel-Vasconcelos ${ }^{(1) *}$, Daniel Jacob Zarin ${ }^{(2)}$, Francisco de Assis \\ Oliveira $^{(3)}$, Steel Silva Vasconcelos ${ }^{(4)}$, Cláudio José Reis de Carvalho ${ }^{(5)}$ and Maria Marly de \\ Lourdes Silva Santos $^{(3)}$
}

\footnotetext{
(1) Universidade Federal Rural da Amazônia, Programa de Pós-graduação em Ciências Florestais, Belém, Pará, Brasil.

(2) Climate and Land Use Alliance of Norwegian Agency for Development Cooperation, San Francisco, California, USA.

(3) Universidade Federal Rural da Amazônia, Departamento de Ciências Florestais, Belém, Pará, Brasil.

(4) Empresa Brasileira de Pesquisa Agropecuária, Belém, Pará, Brasil.

(5) Empresa Brasileira de Pesquisa Agropecuária, Labex Europa, Montpellier, France.

* Corresponding author.

E-mail: liviaturbay@gmail.com
}

\begin{abstract}
Soil microbial biomass (SMB) plays an important role in nutrient cycling in agroecosystems, and is limited by several factors, such as soil water availability. This study assessed the effects of soil water availability on microbial biomass and its variation over time in the Latossolo Amarelo concrecionário of a secondary forest in eastern Amazonia. The fumigation-extraction method was used to estimate the soil microbial biomass carbon and nitrogen content (SMBC and SMBN). An adaptation of the fumigation-incubation method was used to determine basal respiration $\left(\mathrm{CO}_{2}-\mathrm{SMB}\right)$. The metabolic quotient $\left(q \mathrm{CO}_{2}\right)$ and ratio of microbial carbon:organic carbon $\left(C_{M I C}: C_{O R G}\right)$ were calculated based on those results. Soil moisture was generally significantly lower during the dry season and in the control plots. Irrigation raised soil moisture to levels close to those observed during the rainy season, but had no significant effect on SMB. The variables did not vary on a seasonal basis, except for the microbial $\mathrm{C} / \mathrm{N}$ ratio that suggested the occurrence of seasonal shifts in the structure of the microbial community.
\end{abstract}

Keywords: second-growth forest, irrigation, fumigation-extraction, microbial C, microbial $\mathrm{N}$, microbial $\mathrm{C} / \mathrm{N}$ ratio. 


\title{
RESUMO: EFEITO DA DISPONIBILIDADE DE ÁGUA SOBRE A BIOMASSA MICROBIANA DO SOLO EM FLORESTA SECUNDÁRIA NA AMAZÔNIA ORIENTAL
}

\begin{abstract}
A biomassa microbiana do solo (BMS) exerce papel importante na ciclagem de nutrientes em agroecossistemas, sendo limitada por diversos fatores como a disponibilidade de água no solo. Este trabalho teve como objetivo verificar o efeito da disponibilidade da água do solo sobre a biomassa microbiana e sua variação temporal, em um Latossolo Amarelo concrecionário em uma floresta secundária na Amazônia Oriental. Utilizaram-se o método da fumigação-extração para estimar o carbono e o nitrogênio da biomassa microbiana do solo (C-BMS e N-BMS) e uma adaptação da fumigação-incubação para determinar a respiração basal ( $\mathrm{CO}_{2}$-BMS). Foram calculados o quociente metabólico $\left(q \mathrm{CO}_{2}\right)$ e a relação $\mathrm{C}$ microbiano: $\mathrm{C}$ orgânico $\left(C_{M I C}: C_{O R G}\right)$, a partir desses resultados. A umidade do solo foi significativamente menor durante a estação seca e nas parcelas-controle. A irrigação elevou a umidade do solo em níveis próximos dos valores encontrados na época chuvosa; entretanto, não causou efeito significativo sobre a BMS. Não foi observada sazonalidade das variáveis estudadas, apenas a relação $C / N$ microbiana sugeriu mudança na estrutura da comunidade microbiana com a troca da estação chuvosa para seca.
\end{abstract}

Palavras-chave: capoeira, irrigação, fumigação-extração, C-microbiano, N-microbiano, relação C/N microbiana.

\section{INTRODUCTION}

Secondary forests play a major ecological role in the Amazon region, for playing relevant ecological roles, including the fixation of atmospheric $\mathrm{C}$, conservation of biodiversity, connection between forest remnants, and maintenance of the hydrological regime. In addition, secondary forests play a key role in crop rotation, in traditional shifting cultivation systems of the region (Vliet et al., 2013), by increasing soil biomass and nutrients to meet the nutritional demands of crops (Schroth and Lehmann, 2003; Denich et al., 2004). Therefore, studies on nutrient cycling in the secondary forests of Amazonia are extremely important from both an ecological and agronomic standpoint.

Soil microbial biomass (SMB) is an important parameter of nutrient cycling in ecosystems, because it is the fraction of soil organic matter (SOM) that is most rapidly decomposed. The dynamics of SMB are determined by biotic and abiotic factors that vary in space and over time in both natural and man-modified ecosystems (Jenkinson and Ladd, 1981; Wardle and Hungria, 1994). Variation in SMB over time is closely associated with changes in water availability in the soil (Patel et al., 2010), and its study contributes to the understanding of release and mineralization patterns (Wardle, 1998) of nutrients that will consequently be available for plants (Singh et al., 1989; Luizão et al., 1992).

The patterns in temporal variation of SMB in temperate climate are already well understood; they are closely associated with seasonal changes of temperature and hydrological regime (Wardle, 1998). In tropical soils, where temperatures do not vary greatly, water regime plays a major role in the dynamics of soil microbiota (Lodge et al., 1994). However, few studies have been conducted in tropical environments that describe the variation of SMB in relation to water availability in tropical soils.

The effects of abiotic factors, such as water, on the functioning of ecosystems can be assessed by observational or manipulative experiments (Sala and Jackson, 2000). Observational experiments on the effects of soil moisture usually consist of the evaluation of variables over periods of differing precipitation rates (e.g., dry and rainy periods), whereas manipulative experiments involve an increase or reduction in the input of water into the ecosystem, by irrigation or absence of precipitation, respectively (Meir et al., 2009). Our study was developed in the context of an experiment involving the manipulation of soil water availability in a secondary forest in eastern Amazonia, resulting in alterations in several processes of the ecosystem, including the flow of greenhouse gases (Vasconcelos et al., 2004), input and decomposition of leaf litter (Vasconcelos et al., 2007; 2008), net primary productivity (Vasconcelos et al., 2012), and leaf gas exchanges (Fortini et al., 2003).

The objective of this study was to assess the response of microbiological variables and their temporal variation to changes in soil water availability resulting from seasonality of rainfall and irrigation during the dry season.

\section{MATERIAL AND METHODS}

\section{Experimental area and sampling}

The experimental area consisted of a 15-year-old secondary forest colonizing an area abandoned after multiple cycles of slash-and-burn agriculture. It was 
located at the Fish Farming Station of the Rural Federal University of Amazonia (Universidade Federal Rural da Amazonia), alongside the BR 316, $\mathrm{km} \mathrm{63}$, in the region of Apeú, Castanhal, in the watershed of the River Praquiquara, Baixo Guamá $\left(1^{\circ} 19^{\prime} \mathrm{S}, 47^{\circ} 57^{\prime} \mathrm{W}\right)$. The climate is classified as AM3 (Köppen classification), with annual rainfall between 2,000 and $2,500 \mathrm{~mm}$. The rainy season lasts from December to May, and the dry season from June to November. The relative air humidity varies between 78 and $90 \%$. The soil was characterized as phase I Latossolo Amarelo distrófico (concretionary, laterite) (Oxisol), and the vegetation classified as secondary broadleaf forest. The chemical composition of the soil is shown in table 1.

In September 1999, eight $20 \times 20 \mathrm{~m}$ plots were established, spaced at least $10 \mathrm{~m}$ apart. Four plots were randomly assigned to receive irrigation treatments during the dry season, and the others the control treatment (no irrigation). In August 2001, during the dry season, micro-sprinkler irrigation was initiated, i.e., $5 \mathrm{~mm}$ of water was applied daily, corresponding to the evapotranspiration rate of the regional native forests (Jipp et al., 1998).

Soil sampling was performed at a depth of 0-10 cm in November 2000 (dry season), April 2001 (rainy season), and October 2001 (dry season), after three months of irrigation treatment. Six soil cores were combined to provide one composite sample for each experimental plot. Figure 1 show the rainfall events that occurred in the 30 days before sampling.

\section{Sample preparation and laboratory procedures}

The samples were stored in plastic bags and maintained at a temperature of $4{ }^{\circ} \mathrm{C}$ until analysis. They were ground, sieved $(<2-\mathrm{mm})$, and mixed. All plant and animal residues were removed.

The moisture of the samples collected in the dry seasons, in November 2000 and October 2001, was standardized to $60 \%$ of the maximum water retention capacity. To facilitate sieving, the samples collected in April 2001 were air-dried for one night, for being very wet. The samples had a relative moisture content of approximately $60 \%$ of the maximum water retention capacity. Soil gravimetric moisture was determined as proposed by Embrapa (1997).

\section{Organic carbon, soil microbial biomass carbon and soil microbial biomass nitrogen}

Organic carbon $\left(\mathrm{C}_{\mathrm{ORG}}\right)$ was determined by a colorimetric method based on the oxidation of organic matter by a sulfochromic solution and heating, and adapted from Baker (1976).

To determine soil microbial biomass carbon (SMBC) and nitrogen (SMBN), we used SMB fumigation-extraction (Brookes et al., 1985; Vance et al., 1987; Tate et al., 1988). The extraction was performed using $\mathrm{K}_{2} \mathrm{SO}_{4}$ $\left(0.5 \mathrm{~mol} \mathrm{~L}^{-1}\right)$ on non fumigated samples and fumigated samples in alcohol-free chloroform. Microbial C was determined using the colorimetric method (Anderson and Ingram, 1993) and microbial nitrogen determined by the Kjeldahl method (Embrapa, 1997). The $\mathrm{K}_{\mathrm{EC}}$ used was 0.26 (Feigl et al., 1995) and $\mathrm{K}_{\mathrm{EN}}$ was 0.54 (Brookes et al., 1985; Joergensen and Müeller, 1996).

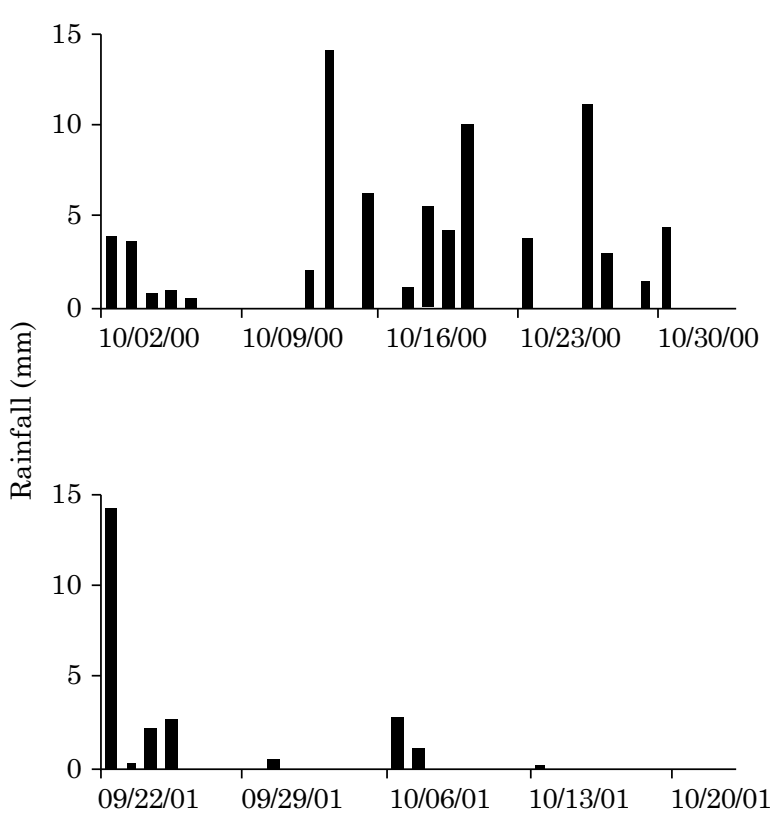

Figure 1. Daily rainfall events in the 30 days before sampling in the dry season of 2000 (on November 2, 2000) (a) and of 2001 (on October 2, 2001) (b).

Table 1. Soil chemical characterization of a 15-year-old secondary forest in eastern Amazonia

\begin{tabular}{|c|c|c|c|c|c|c|c|c|}
\hline Depth & $\mathrm{pH}\left(\mathrm{H}_{2} \mathrm{O}\right)$ & $\mathrm{C}_{\text {ORG }}$ & Total N & $\mathrm{Ca}^{2+}$ & $\mathrm{Mg}^{2+}$ & $\mathbf{K}^{+}$ & $\mathrm{Al}^{3+}$ & $\mathbf{P}$ \\
\hline $\mathrm{cm}$ & & \multicolumn{2}{|c|}{$\mathrm{g} \mathrm{kg}^{-1}$} & \multicolumn{4}{|c|}{$\mathrm{cmol}_{\mathrm{c}} \mathrm{kg}^{-1}$} & $\mathrm{mg} \mathrm{dm}^{-3}$ \\
\hline $0-5$ & 5.0 & 28.90 & 1.70 & 1.7 & 0.5 & 0.05 & 2.3 & 1.60 \\
\hline $5-10$ & 5.1 & 19.80 & 1.40 & 1.4 & 0.4 & 0.05 & 3.2 & 1.56 \\
\hline
\end{tabular}

pH in water (1:2,5 soil:solution); $\mathrm{C}_{\mathrm{ORG}}$ : organic carbon (Baker, 1976); Total N: determined by Kjeldahl's digestion; K and P: extracted by Mehlich-1; Ca, $\mathrm{Mg}$ and $\mathrm{Al}$ : extracted by $\mathrm{KCl} 1 \mathrm{~mol} \mathrm{~L}{ }^{-1}$. 


\section{Microbial biomass basal respiration}

Microbial biomass basal respiration $\left(\mathrm{CO}_{2}-\mathrm{SMB}\right)$ was estimated using an adaptation of the fumigation-incubation method (Jenkinson and Powlson, 1976), which consisted of the incubation of soil samples for 10 days in a container of $\mathrm{NaOH}$, to capture $\mathrm{CO}_{2}$ released by SMB. During the experimental period, the samples were standardized to $75 \%$ of the maximum water retention capacity without humidity correction.

\section{Calculated indices and ratios}

The $\mathrm{C}_{\mathrm{MIC}}$ : $\mathrm{C}_{\mathrm{ORG}}$ ratio was determined using the results of the SMBC and soil organic carbon analyses. The metabolic quotient $\left(q \mathrm{CO}_{2}\right)$ (Santruckova and Straskraba, 1991), also called microbial biomass respiratory quotient (MBRQ) according to Gama-Rodrigues et al. (1997), was calculated using the microbial biomass basal respiration and microbial biomass carbon data.

\section{Statistical analysis}

The effects of irrigation, sampling period, and interactions between irrigation and sampling period were tested using analysis of variance of repeated measurements considering a two-factor design. The differences between means were tested by Tukey's test at a significance of $5 \%$. Statistical analyses were performed using SigmaStat software, v. 2.0 (Jandel Scientific, 1994).

\section{RESULTS}

The results showed a significant effect of the interaction between irrigation and sampling period on soil gravimetric moisture (Table 2). During the dry season (November 2000), the gravimetric moisture contents were approximately half the values measured in the rainy period (April 2001) (Figure 2). During the irrigation period, gravimetric moisture was significantly higher in the irrigated plots than the control plots, approximately $80 \%$ of the values measured in the rainy period (Figure 2).
There was no interaction effect between sampling period and treatment, though sampling period did have a significant effect on the following variables: $\mathrm{C}_{\mathrm{ORG}}, \mathrm{SMBC}, \mathrm{SMBN}, \mathrm{CO}_{2}-\mathrm{SMB}, q \mathrm{CO}_{2}, \mathrm{C}_{\mathrm{MIC}}: \mathrm{C}_{\mathrm{ORG}}$, and C: $\mathrm{N}_{\text {MIC }}$ (Table 2).

The SMBC values varied between 469 and $924 \mu \mathrm{g} \mathrm{g}^{-1}$ of $\mathrm{C}$ and were significantly higher in November 2000 (dry season) than in the other sampling periods (Table 3 ). The SMBN varied between 34 and $63 \mu \mathrm{g} \mathrm{g}^{-1}$ of $\mathrm{N}$, and was significantly higher in November 2000 and April 2001. The microbial C:N ratio varied between 9 and 19, and was significantly higher in October 2001 (dry season) and lower in April 2001 (rainy season).

The values of soil microbial biomass basal respiration $\left(\mathrm{CO}_{2}\right.$ - $\left.\mathrm{SMB}\right)$ were significantly different among all sampling periods (Table 3 ). The metabolic quotient $\left(q \mathrm{CO}_{2}\right)$, which also increased with time, was significantly higher in April and October 2001 (Table 3).

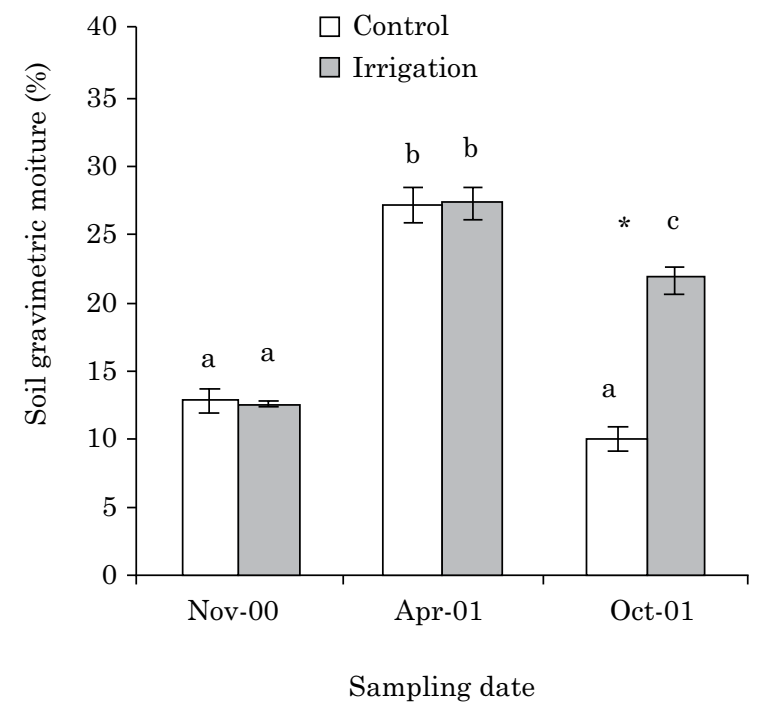

Figure 2. Soil gravimetric moisture under 15-year-old secondary vegetation $(n=12)$ according to the sampling date and irrigation; * indicates a significant difference between irrigation treatments; means followed by the same letters, for each irrigation treatment, do not differ by Tukey's test at $5 \%$. Vertical bars represent the standard error.

Table 2. Analysis of variance of soil gravimetric moisture (M), soil microbial biomass carbon and nitrogen (SMBC and $\mathrm{SMBN})$, soil microbial biomass basal respiration $\left(\mathrm{CO}_{2}-\mathrm{SMB}\right)$, metabolic quotient $\left(q \mathrm{CO}_{2}\right)$, organic carbon $\left(\mathrm{C}_{\mathrm{ORG}}\right)$, and microbial carbon/organic carbon ratio $\left(\mathrm{C}_{\mathrm{MIC}}: \mathrm{C}_{\mathrm{ORG}}\right)$ in a 15 -year-old secondary forest in eastern Amazonia

\begin{tabular}{|c|c|c|c|c|c|c|c|}
\hline Variation source & $\mathbf{M}$ & SMBC & SMBN & $\mathrm{CO}_{2}$-SMB & $q \mathrm{CO}_{2}$ & C ORG $_{\text {OR }}$ & $\mathrm{C}_{\mathrm{MIC}}: \mathrm{C}_{\mathrm{ORG}}$ \\
\hline Irrigation (I) & $0.005^{* *}$ & 0.529 & 0,909 & 0.684 & 0.532 & 0.113 & 0.399 \\
\hline Sampling date (D) & $<0.001 * * *$ & $<0.001 * * *$ & $<0,001^{* * *}$ & $<0.001 * * *$ & $<0.001 * * *$ & $<0.001^{* * *}$ & $<0.001 * * *$ \\
\hline Interaction $\mathrm{I} \times \mathrm{D}$ & $<0.001 * * *$ & 0.829 & 0,460 & 0.797 & 0.712 & 0.448 & 0.807 \\
\hline
\end{tabular}


Table 3. Soil microbial biomass carbon (SMBC), soil microbial biomass nitrogen (SMBN), microbial biomass basal respiration $\left(\mathrm{CO}_{2}\right.$-SMB), soil organic carbon $\left(\mathrm{C}_{\mathrm{ORG}}\right)$, metabolic quotient $\left(q \mathrm{CO}_{2}\right)$, soil $\mathrm{C}_{\text {MIC }}: \mathrm{C}_{\mathrm{ORG}}$ ratio, and $\mathrm{C}: \mathrm{N}_{\text {MICROBIAL }}$ ratio $($ depth of 0-10 cm) under a 15-year-old secondary forest of eastern Amazonia in different sampling periods (mean \pm standard error, $n=8$ )

\begin{tabular}{lccc}
\hline \multirow{2}{*}{ Parameter } & \multicolumn{3}{c}{ Sampling period } \\
\cline { 2 - 4 } & November 2000 & April 2001 & October 2001 \\
\hline $\mathrm{SMBC}\left(\mu \mathrm{g} \mathrm{g}^{-1}\right.$ of $\left.\mathrm{C}\right)$ & $924 \pm 68 \mathrm{~A}$ & $469 \pm 34 \mathrm{~B}$ & $538 \pm 42 \mathrm{~B}$ \\
$\mathrm{SMBN}\left(\mu \mathrm{g} \mathrm{g}^{-1}\right.$ of $\left.\mathrm{N}\right)$ & $63 \pm 4 \mathrm{~A}$ & $54 \pm 5 \mathrm{~A}$ & $34 \pm 5 \mathrm{~B}$ \\
$\mathrm{CO}_{2}-\mathrm{SMB}\left(\mu \mathrm{g} \mathrm{g}^{-1} \mathrm{~h}^{-1} \mathrm{C}^{\left.-\mathrm{CO}_{2}\right)}\right.$ & $1.6 \pm 0.1 \mathrm{~A}$ & $2.8 \pm 0.2 \mathrm{~B}$ & $3.9 \pm 0.3 \mathrm{C}$ \\
$\mathrm{C}_{\mathrm{ORG}}(\%)$ & $1.46 \pm 0.1 \mathrm{~A}$ & $1.49 \pm 0.2 \mathrm{AB}$ & $1.81 \pm 0.2 \mathrm{~B}$ \\
$q \mathrm{CO}_{2}$ & $0.002 \pm 1^{-4} \mathrm{~A}$ & $0.006 \pm 61^{-4} \mathrm{~B}$ & $0.008 \pm 81^{-4} \mathrm{~B}$ \\
$\mathrm{C}_{\mathrm{MIC}}: \mathrm{C}_{\mathrm{ORG}}$ & $8.1 \pm 1.0 \mathrm{~A}$ & $3.1 \pm 0.3 \mathrm{~B}$ & $3.1 \pm 0.4 \mathrm{~B}$ \\
$\mathrm{C}: \mathrm{N}_{\text {MICROBIAL }}$ & $15 \pm 1 \mathrm{AB}$ & $9 \pm 1 \mathrm{~B}$ & $19 \pm 4 \mathrm{~A}$ \\
\hline
\end{tabular}

Means followed by the same letters do not differ significantly (Tukey's test at $5 \%$ ).

The values of soil organic $\mathrm{C}$ differed between the two dry periods; however, they were statistically similar to those in the rainy season. The $\mathrm{C}_{\mathrm{MIC}}: \mathrm{C}_{\mathrm{ORG}}$ ratio was significantly higher in November 2000 than in the other sampling periods. (Table 3).

\section{DISCUSSION}

The values for SMBC and SMBN agreed with results of earlier studies conducted in the same region (Rangel-Vasconcelos et al., 2005; Sotta et al., 2008; Lopes et al., 2011; Melo et al., 2012). Bittencourt et al. (2006) found a higher SMBN content in Amazonian soils under secondary vegetation in the rainy season. Other studies in tropical forests indicated that seasonal variation in soil moisture is associated with seasonal variation in soil microbial C and N (Singh et al., 1989; Luizão et al., 1992; Srivastava, 1992). However, in this study no clear pattern of soil microbial mass variation associated with seasonal changes in soil moisture was observed.

The high concentrations of SMBC and SMBN in the first soil sampling, during the dry season, may have been the result of nutrient release from dead SMB and/or the decomposition of leaf litter, in addition to rainfall in the days before sampling. Prolonged dry periods followed by rainfall cause osmotic stress in microbial cells and promote cell lysis, resulting in the release of a pulse of nutrients (Lodge et al., 1994; Wardle, 1998; Yang et al., 2008), that become available to the soil microbiota and plants (Singh et al., 1989; Srivastava, 1992). In fact, pulses of soil $\mathrm{CO}_{2}$ efflux, possibly associated with the increase in microbial activity, were observed in the same experimental area in response to rainfall during prolonged dry periods (Vasconcelos et al., 2004). In addition, in the dry season, there is an accumulation of leaf litter as a combined consequence of increased litter production and reduced decomposition rate (Vasconcelos et al., 2007; 2008). Therefore, rainfall in the dry season favors the release of nutrients from the accumulated leaf litter, which benefits the soil microbial biomass.

The occurrence and amount of daily precipitation during the 30 days preceding the two samplings performed in the dry season (November 2000 and October 2001) are shown in figure 1. In the first soil sampling, pluvial precipitation was $77 \mathrm{~mm}$ during the 30 preceding days, $17 \mathrm{~mm}$ of which fell in the week immediately before sampling, characterizing a period of possible nutrient pulses (Lodge et al., 1994). Prior to the October 2001 sampling, precipitation was $24 \mathrm{~mm}$ in the preceding 30 days (no rain fell in the 15 days before sampling).

The values of basal respiration were higher than those found by previous studies conducted in

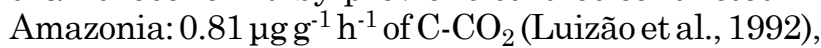
0.35 to $0.70 \mathrm{\mu g} \mathrm{g}^{-1} \mathrm{~h}^{-1}$ of C-CO $\mathrm{CO}_{2}$ (Gama-Rodrigues et al., 1994), and 0.85 to $1.11 \mu \mathrm{g} \mathrm{g}^{-1} \mathrm{~h}^{-1} \mathrm{C}-\mathrm{CO}_{2}$ (Melo et al., 2012). This may have been a result of soil-climatic differences, as well as differences between the methods used to determine basal respiration. In general, there was an increase in carbon mineralization during the observation period, rather than the expected increase in the amount of SMBC. Over time, $q \mathrm{CO}_{2}$ lost efficiency, since carbon was mineralized at a faster rate than it was fixed, indicating that the greater the amount of carbon in SMB, the lower its mineralization rate and vice-versa (Santruckova and Straskaba, 1991; Gama-Rodrigues et al., 1997). Contrary to what was expected, the high respiration rate in the third sampling (October 2001) indicated an increase in microbial activity, although this increase was not stimulated by soil water availability.

Although no consistent pattern of seasonality was observed for SMBC and SMBN during the experiment, the microbial $\mathrm{C} / \mathrm{N}$ ratio tended to vary 
on a seasonal basis, suggesting an alteration in the microbial community composition with the changes between dry and rainy seasons. Bacterial microbiota is richer in proteins, and therefore in $\mathrm{N}$ content, than fungal microbiota (resulting in a lower $\mathrm{C} / \mathrm{N}$ ratio) (Anderson and Domsch, 1980; Brady, 1989; Tate, 2000). Ross (1987) characterized the C and $\mathrm{N}$ contents of soil microorganisms and observed a C:N ratio of 22 for Penicillium novae-zelandiae, but a C:N ratio for Pseudomonas sp. of 3.3.

Cornejo et al. (1994) studied the effects of irrigation on the microbial community structure in a tropical forest and observed a higher density of bacteria and a lower density of fungi in an irrigated plot. On the other hand, Holland et al. (2013) found a higher density of fungi in soils under grape cultivation with periods of irrigation.

Repeated cycles of soil drying and wetting can favor the growth of microbial populations adapted to these conditions. Marschner et al. (2002) demonstrated that bacteria and fungi are able to tolerate sudden changes in soil matric potential, and grow rapidly with the availability of nutrients from the labile fraction of soil organic matter or dead microorganisms. However, fungi can respond better to fluctuating conditions of soil moisture and survive periods of drought, for being more resistant to osmotic stress (Wardle, 2002; Coleman et al., 2004).

The $\mathrm{C}_{\mathrm{ORG}}$ content increased over the observation period, possibly as a result of the increase in phytomass, production of net organic matter, and secondary vegetation succession (Vieira, 1996; Rangel-Vasconcelos et al., 2005). The values of $\mathrm{C}_{\mathrm{MIC}}: \mathrm{C}_{\mathrm{ORG}}$ indicate the extent to which soil $\mathrm{C}_{\mathrm{ORG}}$ is in the form of SMB, and the extent to which $\mathrm{C}_{\mathrm{ORG}}$ will return to the atmosphere in the form of $\mathrm{CO}_{2}$. Usually, SMB represents between 1 and $5 \%$ of total $\mathrm{C}_{\mathrm{ORG}}$ in the soil (Powlson and Jenkinson, 1981; Balota et al., 1998). According to Anderson and Domsch (1989), the $\mathrm{C}_{\mathrm{MIC}}: \mathrm{C}_{\mathrm{ORG}}$ ratio varies between 0.3 and $7 \%$. Basante et al. (2001) observed values between 3 and $11 \%$ in the native forests of Amazonia, whereas Rangel-Vasconcelos et al. (2005) reported values between 2 and $18 \%$ in secondary vegetation of various ages.

\section{CONCLUSIONS}

The increase in soil water availability resulting from irrigation during the dry season and under the experimental conditions of this study had no effect on soil microbial biomass.

Carbon, nitrogen, and microbial activity indicated no seasonality in relation to the dry and rainy seasons.
The microbial $\mathrm{C} / \mathrm{N}$ ratio indicated no seasonality; however, the results indicated changes in the microbial community according to the sampling period.

\section{REFERENCES}

Anderson JM, Ingram ISI. Tropical soil biology and fertility: A handbook of methods. $2^{\text {a }}$ ed. Wallingford: Commonwealth Agricultural Bureaux International; 1993.

Anderson TH, Domsch KH. Quantities of plant nutrients in the microbial biomass of selected soils. Soil Sci. 1980;130:211-6.

Anderson TH, Domsch KH. Ratios of microbial biomass carbon to total organic in arable soils. Soil Biol Biochem. 1989;4:471-9.

Baker KF. The determination of organic carbon in soil using a probe-colorimeter. Labor Pract. 1976;25:82-3.

Balota EL, Colozzi-Filho A, Andrade DS, Hungria M. Biomassa microbiana e sua atividade em solos sob diferentes sistemas de preparo e sucessão de culturas. R Bras Ci Solo. 1998;22:641-9.

Basante FT, Silva Jr ML, Melo VS, Costa LGS, McNabb KL. Atividade, carbono da biomassa microbiana de latossolo amarelo com diferentes texturas sob floresta nativa e floresta plantada com eucalipto. In: Resumos do $3^{\circ}$ Seminário de Iniciação Científica da Faculdade de Ciências Agrárias do Pará, 2001. Belém: Faculdade de Ciências Agrárias do Pará; 2001. p.52-4.

Bittencourt KSQQ, Santos MMLS, Morais FIO, Silva Júnior ML, Melo VS, Soares NT. Nitrogênio da biomassa microbiana em Argissolo Vermelho-Amarelo sob mata de Cerrado, área de cultivo de grãos e pastagem natural de Redenção-Pará. R Bras Ci Solo. 2006;45:187-203.

Brady NC. Natureza e propriedades dos solos. $7^{\text {a }}$ ed. Rio de Janeiro: Freitas Bastos; 1989.

Brookes PC, Landman A, Pruden G, Jenkinson DS. Chloroform fumigation and the release of soil nitrogen: A rapid direct extraction method to measure microbial biomass nitrogen soil. Soil Biol Biochem. 1985;17:837-42.

Coleman DC, Crossley Jr DA, Hendrix PF. Fundamentals of soil ecology. $2^{\text {a }}$ ed. San Diego: Elsevier Academic; 2004.

Cornejo FH, Varela A, Wright JS. Tropical forest litter decomposition under seasonal drought: Nutrient release, fungi and bacteria. Oikos. 1994;70:183-90.

Denich M, Vielhauer K, Kato M, Block A, Kato OR, Sa T, Lucke W, Vlek PLG. Mechanized land preparation in forest-based fallow systems: The experience from Eastern Amazonia. Agrofor Syst. 2004;61:91-106.

Empresa Brasileira de Pesquisa Agropecuária - Embrapa. Manual de métodos de análise de solo. Rio de Janeiro; Centro Nacional de Pesquisa em Solo; 1997. (Documentos, 1).

Feigl BJ, Sparling GP, Ross DJ, Cerri CC. Soil microbial biomass in Amazonian soils: Evaluation of methods and estimates of pool sizes. Soil Biol Biochem. 1995;27:1467-72.

Fortini LB, Mulkey SS, Zarin DJ, Vasconcelos SS, Carvalho CJR. Drought constraints on leaf gas exchange by Miconia ciliata (Melastomataceae) in the understory of an eastern Amazonian regrowth forest stand. Am J Bot. 2003;90:1064-70. 
Gama-Rodrigues EF, Gama-Rodrigues AC, Barros NF. Biomassa microbiana de carbono e de nitrogênio de solos sob diferentes coberturas florestais. R Bras Ci Solo. 1997;21:361-5.

Gama-Rodrigues EF, Guerra JGM, Almeida DL, De-Polli H. Biomassa microbiana de carbono em solos de Itaguaí (RJ): Comparação entre os métodos fumigação-incubação e fumigaçãoextração. R Bras Ci Solo. 1994;18:427-32.

Holland TC, Reynoldsb AG, Bowenc PA, Bogdanoffc CP, Marciniakb M, Brownd RB, Harta MM. The response of soil biota to water availability in vineyards. Pedobiologia. 2013;56:9-14

Jandel Scientific. SigmaStat user guide. San Rafael: Jandel Scientific; 1994.

Jenkinson DS, Ladd JN. Microbial biomass in soils: Measurement and turnover. In: Paul EA, Ladd JN, editors. Soil biochemistry. $5^{\mathrm{a}}$ ed. New York: Marcel Decker; 1981. p.415-7.

Jenkinson DS, Powlson DS. Residual effects of soil fumigation on soil respiration and mineralization. Soil Biol Biochem. 1976;2:99-108.

Jipp PH, Nepstad DC, Cassel K, Carvalho CRD. Deep soil moisture storage and transpiration in forests and pastures of seasonally-dry Amazonia. Clim Change. 1998;39:395-412.

Joergensen RG, Müeller T. The fumigation-extraction method to estimate soil microbial biomass: Calibration of the $\mathrm{k}_{\mathrm{EN}}$ value. Soil Biol Biochem. 1996;28:33-7.

Lodge DJ, McDowell WH, McSwiney CP. The importance of nutrient pulses in tropical forests. Trends Ecol Evol. 1994;9:384-7.

Lopes ELN, Fernandes ARF, Ruivo MLP, Cattanio JH, Souza GF. Microbial biomass and soil chemical properties under different land use systems in notheaster Pará. R Bras Ci Solo. 2011;35:1127-39.

Luizão RCC, Bonde TA, Rosswall T. Seasonal variation of soil microbial biomass - the effects of clearfelling a tropical rainforest and establishment of pasture in the central Amazon. Soil Biol Biochem. 1992;24:805-13.

Marschner P, Marino W, Lieberei, R. Seasonal effects on microorganisms in the rhizosphere of two tropical plants in a polyculture agroforestry system in Central Amazonia, Brazil. Biol Fertil Soils. 2002;35:68-71.

Meir P, Brando PM, Nepstad D, Vasconcelos SS, Costa ACL, Davidson EA, Almeida S, Fisher RA, Sotta ED, Zarin DJ, Cardinot G. The effects of drought on Amazonian rain forests. In: Keller M, Bustamante M, Gash J, Dias PS., organizers. Amazonia and global change. Washington: American Geophysical Union; 2009. p.429-49.

Melo V, Desjardins T, Silva Jr ML, Santos ER, Sarrazin M, Santos MMLS. Consequences of forest conversion to pasture and fallow on soil microbial biomass and activity in the eastern Amazon. Soil Use Manage. 2012;28:530-5.

Patel K, Kumar J, Kumar RN, Kumar B. Seasonal and temporal variation in soil microbial biomass $\mathrm{C}, \mathrm{N}$ and $\mathrm{P}$ in different types land uses of dry deciduous forest ecosystem of Udaipur, Rajasthan, Western India. Appl Ecol Environ Res. 2010;8:377-90.

Powlson DS, Jenkinson DS. A comparison of the organic matter, biomass, adenosine triphosphate and mineralizable nitrogen contents of ploughed and direct-drilled soils. J Agric Sci. 1981;97:713-21.
Rangel-Vasconcelos LGT, Zarin DJ, Carvalho CJR, Santos MMLS, Vasconcelos SS, Oliveira FA. Carbono, nitrogênio e atividade da biomassa microbiana de um solo sob vegetação secundária de diferentes idades na Amazônia Oriental. R Ci Agrár. 2005;44:49-63.

Ross DJ. Soil microbial biomass estimate by the FI procedure: Seasonal fluctuations and influence of soil moisture content. Soil Biol Biochem. 1987;19:397-404.

Sala OE, Jackson RB. Methods in ecosystem science. New York: Springer; 2000.

Santruckova H, Straskaraba M. On the relationship between specific respiration activity and microbial biomass in soils. Soil Biol Biochem. 1991;23:525-32.

Schroth G, Lehmann J. Nutrient capture. In: Schroth G, Sinclair FL, editors. Trees, crops and soil fertility: Concepts and research methods. Wallingford: Commonwealth Agricultural Bureaux International; 2003. p.167-74

Singh JS, Raghubanshi AS, Singh RS, Srivastava SC. Microbial biomass acts as a source of plant nutrients in dry tropical forest and savanna. Nature, 1989;338:499-500.

Sotta ED, Corre MD, Veldkamp E. Differing N status and N retention processes of soils under old-growth lowland forest in eastern Amazonia, Caxiuana, Brazil. Soil Biol Biochem. 2008;40:740-50.

Srivastava SC. Microbial C, N and P in dry tropical soils: Seasonal changes and influence of soil moisture. Soil Biol Biochem. 1992;24:711-4.

Tate KR, Ross DJ, Feltham CW. A direct extraction method to estimate soil microbial C: Effects of experimental variables and some different calibration procedures. Soil Biol Biochem. 1988;20:329-35.

Tate RL. Soil microbiology. $2^{\mathrm{a}}$ ed. New York: John Wiley \& Sons; 2000.

Vance ED, Brookes PC, Jenkinson DS. An extraction method for measuring soil microbial biomass C. Soil Biol Biochem. 1987,19:703-7.

Vasconcelos SS, Zarin DJ, Araújo MM, Miranda IDS. Aboveground net primary productivity in tropical forest regrowth increases following wetter dry-seasons. For Ecol Manage. 2012;276:82-7.

Vasconcelos SS, Zarin DJ, Araújo MM, Rangel-Vasconcelos LGT, Carvalho CJR, Staudhammer CL, Oliveira FDA. Effects of seasonality, litter removal and dry-season irrigation on litterfall quantity and quality in eastern Amazonian forest regrowth, Brazil. J Trop Ecol. 2008;24:27-38.

Vasconcelos SS, Zarin DJ, Capanu M, Littell R, Davidson EA, Ishida FY, Santos EB, Araujo MM, Aragao DBV, RangelVasconcelos LGT, Oliveira FDA, McDowell, WH, Carvalho CJR. Moisture and substrate availability constrain soil trace gas fluxes in an eastern Amazonian regrowth forest. Global Biogeochem Cycles. 2004;18:1-10. doi:10.1029/2003GB002210.

Vasconcelos SS, Zarin DJ, Rosa MBS, Oliveira FD. Leaf decomposition in a dry season irrigation experiment in Eastern Amazonian forest regrowth. Biotropica, 2007;39:593-600.

Vieira ICG. Forest succession after shifting cultivation in Eastern Amazonia [tese]. Scotland: University of Stirling; 1996. 
Vliet NV, Adams C, Vieira ICG, Mertz O. "Slash and Burn" and "Shifting" cultivation systems in forest agriculture frontiers from the Brazilian Amazon. Soc Nat Res. 2013;26:1454-1467. doi: $10.1080 / 08941920.2013 .820813$

Wardle DA. Controls of temporal variability of the soil microbial biomass: A global-scale synthesis. Soil Biol Biochem. 1998;30:1627-37.

Wardle DA, Hungria M. A biomassa microbiana do solo e sua importância nos ecossistemas terrestres. In: Araújo RS, Hungria
M, editores. Avanços obtidos nos estudos sobre microrganismos de importância agrícola. Brasília, DF: Empresa Brasileira de Pesquisa Agropecuária; 1994. p.195-216.

Wardle DA. Communities and ecosystems - linking the aboveground and belowground components. Princeton: Princeton University Press; 2002.

Yang LH, Bastow JL, Spence KO, Wright AN. What can we learn from resource pulses. Ecology. 2008;89:621-34. 